Research article

\title{
Increased expression of FcyRI/CD64 on circulating monocytes parallels ongoing inflammation and nephritis in lupus
}

\author{
Yi Li", Pui Y Lee ${ }^{1,2}$, Eric S Sobel ${ }^{1}$, Sonali Narain ${ }^{1}$, Minoru Satoh ${ }^{1}$, Mark S Segal ${ }^{2}$, \\ Westley H Reeves ${ }^{1}$ and Hanno B Richards ${ }^{1,3}$
}

\author{
1'Division of Rheumatology \& Clinical Immunology, University of Florida, 1600 SW Archer Road, Gainesville, FL 32610-0221, USA \\ ${ }^{2}$ Division of Nephrology, Hypertension and Transplantation, Department of Medicine, University of Florida, 1600 SW Archer Road, Gainesville, FL \\ 32610-0221, USA \\ ${ }^{3}$ Schering-Plough Corporation, Kenilworth, NJ 07033-0530, USA
}

Corresponding author: Yi Li, liyi@medicine.ufl.edu

Received: 29 Aug 2008 Revisions requested: 24 Oct 2008 Revisions received: 21 Nov 2008 Accepted: 14 Jan 2009 Published: 14 Jan 2009

Arthritis Research \& Therapy 2009, 11:R6 (doi:10.1186/ar2590)

This article is online at: http://arthritis-research.com/content/11/1/R6

(c) 2009 Li et al.; licensee BioMed Central Ltd.

This is an open access article distributed under the terms of the Creative Commons Attribution License (http://creativecommons.org/licenses/by/2.0), which permits unrestricted use, distribution, and reproduction in any medium, provided the original work is properly cited.

\begin{abstract}
Introduction The high-affinity receptor for $\operatorname{lgG} \mathrm{Fc}_{\mathrm{c}} / \mathrm{CD} 64$ is critical for the development of lupus nephritis (LN). Cross-linking Fc receptor on recruited monocytes by lgG-containing immune complexes is a key step in immune-complex-mediated nephritis in systemic lupus erythematosus (SLE). The goal of this study was to determine whether expression of $F_{c}$ receptor $\left(F_{c} \gamma R\right)$ I on circulating monocytes is associated with systemic inflammation and renal disease in SLE patients.

Methods We studied 205 SLE patients (132 with LN and 73 without LN) along with 74 healthy control individuals. Surface expression of CD14 (monocytes), Fc $\gamma R$ R/CD64, Fc $\gamma$ RII/CD32, and FcyRIII/CD16 was evaluated by flow cytometry. Monocyte function was assessed by determining the migratory capacity and the ability to produce CCL2 (monocyte chemotractic protein 1). High-sensitivity C-reactive protein, $\mathrm{C} 3$ and $\mathrm{C} 4$ were measured by nephelometry.

Results There was little difference in the expression of Fc $\gamma \mathrm{RIII} /$ CD16 or FcyRIII/CD32 on circulating monocytes between patients with SLE and control individuals. In contrast, Fc $\gamma \mathrm{RI} /$ CD64 expression was significantly higher in SLE patients and even higher in patients with LN. Fc $\gamma$ RI/CD64 expression was positively associated with serum creatinine and indicators of systemic inflammation. Monocytes from patients with high FcyRI/CD64 expression also exhibited increased chemotaxis and capacity to produce monocyte chemotractic protein 1.

Conclusions Increased Fc $\gamma \mathrm{RI} / \mathrm{CD} 64$ expression on circulating monocytes parallels systemic inflammation and renal disease in SLE patients. We propose that circulating monocytes activated by immune complexes and/or proinflammatory mediators upregulate surface expression of Fc $\gamma \mathrm{RI} / \mathrm{CD} 64$ in SLE. The enhanced chemotactic and inflammatory potential of the activated monocytes may participate in a vicious cycle of immune cell recruitment and renal injury in SLE.
\end{abstract}

\section{Introduction}

Systemic lupus erythematosus (SLE) is an autoimmune disease characterized by the production of autoantibodies against a wide array of self-antigens [1]. Formation of immune complexes (ICs) between these autoantibodies and the target antigens has been linked to the development of lupus nephritis (LN) $[2,3]$. Deposition of ICs in the kidneys activates monocyte/macrophages by interacting with $\mathrm{Fc}$ receptor $(\mathrm{Fc} \gamma \mathrm{R}) \mathrm{I}$ and Fc $\gamma R$ III, initiating an inflammatory cascade of cytokines and chemokines. The release of proinflammatory mediators such as monocyte chemotractic protein 1 (MCP-1 (CCL2)), macrophage inflammatory protein 1 (CCL3) and fractalkine $\left(\mathrm{CX}_{3} \mathrm{CL} 1\right)$ recruits monocyte/macrophages and other immune effector cells, culminating in tissue damage $[4,5]$.

Three classes of FcyRs are expressed on circulating human monocytes. FcyRI/CD64 is a high-affinity receptor constitutively expressed at substantial levels by monocytes [6]. Monocytes also express high levels of FcyRII/CD32, a low-affinity receptor for ICs with two functionally distinct isoforms. In con-

BSA: bovine serum albumin; CRP: C-reactive protein; DMEM: Dulbecco's modified Eagle's medium; Fc $\gamma$ R: Fc $\gamma$ receptor; IC: immune complex; IFN: interferon; IL: interleukin; LN: lupus nephritis; LPS: lipopolysaccharide; MCP-1: monocyte chemotractic protein 1; PBS: phosphate-buffered saline; SLE: systemic lupus erythematosus; TNF: tumor necrosis factor. 
trast, Fc $\gamma$ RIII/CD16, a receptor with moderate affinity for complexed $\operatorname{lgG}$, is present on only about $10 \%$ to $15 \%$ of circulating monocytes [7]. Fc $\gamma \mathrm{RI}, \mathrm{Fc} \gamma \mathrm{R}$ Ila and Fc $\gamma \mathrm{RIII}$ are activating $F_{c}$ receptors bearing intracytoplasmic tyrosine-based activation motifs that trigger monocyte activation upon receptor aggregation. Fc $\gamma \mathrm{R} / \mathrm{lb}$, on the other hand, contains an immunoreceptor tyrosine-based inhibitory motif and functions as an inhibitory Fc receptor upon interacting with ICs [8].

The balance of activating and inhibitory Fc $\gamma \mathrm{R}$ determines the magnitude of the cellular response in monocytes. Enhanced expression of activating Fc $\gamma$ Rs or decreased expression of the inhibitory Fc $\gamma \mathrm{R}$ can lower the activation threshold, leading to the production of inflammatory cytokines that may promote $\mathrm{LN}$ [9]. Conversely, NZB/W F1 mice deficient in FcyRI/III are protected from LN despite developing extensive IC deposits [10]. As in Wegener's granulomatosis [11] and rheumatoid arthritis [12], circulating monocytes in SLE are activated and exhibit increased surface expression of Fc $\gamma R \mathrm{RI} C \mathrm{CD} 64$ [13]. Whether this increase in activating $\mathrm{Fc} \gamma \mathrm{R}$ on monocytes is related to development of $L N$, however, is unknown.

To investigate the possible role of activating $\mathrm{F}_{\mathrm{c}} \gamma \mathrm{R}$ in human $\mathrm{LN}$, we examined the expression of Fc $\gamma \mathrm{RI} / \mathrm{CD} 64$, Fc $\gamma \mathrm{RIII} /$ CD16 and FcyRII/CD32 on circulating monocytes from SLE patients, and the relationship of $\mathrm{Fc} \gamma \mathrm{R}$ expression levels to renal involvement and chemokine production.

\section{Materials and methods Study population}

The present study was approved by the University of Florida Institutional Review Board, and all subjects provided written informed consent prior to participation. SLE patients met at least four of the revised 1982 American College of Rheumatology criteria [14]. Peripheral blood was collected from 205 patients and 74 healthy control individuals. In the patient group, 132 participants had either biopsy-proven or laboratory-proven LN and 73 had no evidence of LN. At each visit a medication history and key laboratory parameters were collected. Disease activity was assessed using the Systemic Lupus Erythematosus Disease Activity Index [15]. Detailed demographics, clinical characteristics, medication usage and laboratory measurements for all groups are presented in Table 1.

\section{Cell surface staining}

Antibodies were obtained from BD Pharmingen (San Diego, CA, USA) unless indicated otherwise. Heparinized whole blood $(100 \mu \mathrm{l})$ was stained with PerCP-conjugated anti-CD14 (clone MФ P9), fluorescein isothiocyanate-conjugated antiCD16 (clone 3G8), allophycocyanin-conjugated anti-CD32 (clone FLI8.26), anti-HLA-DR (clone LN3), anti-CD62L (clone DREG56; eBioscience, San Diego, CA, USA), phycoerythrinconjugated anti-CD64 (clone X54-5/7.1.1), and anti-CD16 (clone $3 \mathrm{G} 8$ ) for 30 minutes in the dark. Following lysis of eryth- rocytes, cells were washed with $\mathrm{PBS} / 1 \% \mathrm{BSA} / 0.01 \% \mathrm{NaN}_{3}$ and were fixed in $2 \%$ paraformaldehyde PBS. Cells $\left(10^{5}\right)$ were analyzed using a FACSCalibur flow cytometer and CellQuest software (Becton Dickinson, Mountain View, CA, USA).

Gates were set around monocytes based on their forward/ sideward light scatter pattern and CD14 expression. Surface marker expression levels were expressed as the geometrical mean fluorescence intensity on monocytes. Since not all CD14 monocytes express CD16, CD32, CD62L and HLA$\mathrm{DR}$, expression was also expressed as the percentage of positive monocytes. Data analysis was performed using FCS Express 2.0 (De Novo Software, Thornhill, ON, Canada).

\section{Analysis of chemokine production}

Heparinized whole blood was diluted 1:1 with DMEM (Mediatech, Inc., Herndon, VA, USA) containing 10\% fetal bovine serum (Mediatech, Inc.), and was stimulated with lipopolysaccharide (LPS) $(500 \mathrm{ng} / \mathrm{ml}$, from Escherichia coli; Sigma Chemical Company, St Louis, MO, USA) or C-reactive protein (CRP) $(50 \mathrm{ng} / \mathrm{ml}$, purified from human serum, endotoxin-free; Calbiochem, La Jolla, CA, USA) in the presence of the protein transport inhibitor GolgiStop ${ }^{\mathrm{TM}}$ (BD Pharmingen). In all cases, cells were incubated at $37^{\circ} \mathrm{C}$ in a $5 \% \mathrm{CO}_{2}$ atmosphere for 4 hours. The dose of LPS and CRP and the length of incubation were optimized for chemokine production in preliminary experiments. Immediately after incubation, $100 \mu \mathrm{l}$ aliquots of cells were stained with appropriate combinations of monoclonal antibodies for 30 minutes at $22^{\circ} \mathrm{C}$ in the dark. After incubation, $2 \mathrm{ml}$ PharMlyse (BD Pharmingen) was added to lyse erythrocytes. After washing, cells were fixed and permeabilized with $200 \mu$ Cytofix/Cytoperm solution (BD Pharmingen) for 20 minutes at $4^{\circ} \mathrm{C}$. After two washes with Perm/Wash solution (BD Pharmingen), cells were resuspended in $100 \mu \mathrm{l} \mathrm{Perm/}$ Wash solution containing $1.5 \mu \mathrm{g} / \mu \mathrm{l}$ phycoerythrin-conjugated anti-MCP-1 clone (5D3-F7; BD Pharmingen) or the same concentration of phycoerythrin-conjugated mouse $\lg \mathrm{G} 1$ as an isotype control. After incubating at $4^{\circ} \mathrm{C}$ for 30 minutes in the dark, cells were washed and analyzed by flow cytometry.

\section{Chemotaxis assay}

Peripheral blood mononuclear cells isolated from SLE patients and from healthy control individuals using Ficoll-Hypaque density gradient centrifugation were washed once and resuspended in DMEM containing $0.5 \%$ fetal bovine serum at a concentration of $10^{7}$ cells $/ \mathrm{ml}$. Medium containing MCP-1 (25 $\mathrm{ng} / \mathrm{ml}$; Research Diagnostics Inc., Flanders, NJ, USA) or medium alone as a control were added to the lower chambers of a 24-well Costar Transwell plate (Corning Inc. Corning, NY, USA). The cell suspension (100 $\mu \mathrm{l})$ was added to the upper chamber, which was separated from the lower chamber by a polycarbonate membrane ( $8.0 \mu \mathrm{m}$ pores). After incubation for 3 hours at $37^{\circ} \mathrm{C}$, cells in the lower chamber were collected, stained with anti-CD14, anti-CD16, and anti-HLA-DR, and analyzed by flow cytometry. Results are presented as a migra- 
Demographics, laboratory characteristics and clinical characteristics of participants

\begin{tabular}{|c|c|c|c|}
\hline & Control individuals $(n=74)$ & SLE patients without $L N(n=73)$ & SLE patients with $L N(n=132)$ \\
\hline \multicolumn{4}{|l|}{ Demographics } \\
\hline Female (\%) & 93 & 93 & 90 \\
\hline Mean age (years) & 38 & 37 & 35 \\
\hline \multicolumn{4}{|l|}{ Race (\%) } \\
\hline African-American & 37 & 31 & 43 \\
\hline Caucasian & 32 & $49^{\star}$ & $32^{+}$ \\
\hline Others & 31 & 20 & 25 \\
\hline Disease duration (years) & - & $9.0 \pm 0.8$ & $10.3 \pm 0.8$ \\
\hline $\begin{array}{l}\text { American College of Rheumatology } \\
\text { criteria count }\end{array}$ & - & $6.0 \pm 0.2$ & $6.4 \pm 0.2$ \\
\hline \multicolumn{4}{|l|}{ Serum markers } \\
\hline C3 (mg/dl) & $125.1 \pm 5.3$ & $100.0 \pm 3.7^{\star}$ & $92.6 \pm 5.0^{*}$ \\
\hline $\mathrm{C} 4$ (mg/dl) & $24.7 \pm 2.1$ & $17.0 \pm 1.1$ & $19.4 \pm 1.5$ \\
\hline High-sensitivity C-reactive protein (mg/dl) & $1.4(1.1$ to 4.4$)$ & $5.5(4.1 \text { to } 7.0)^{*}$ & $5.8(4.0 \text { to } 7.5)^{\star}$ \\
\hline \multicolumn{4}{|l|}{ SLE manifestationa $(\%)$} \\
\hline Central nervous system & - & 21 & 14 \\
\hline Skin & - & 65 & 53 \\
\hline Joint & - & 87 & 68 \\
\hline Serositis & - & 31 & 35 \\
\hline Anti-dsDNA & - & 45 & $78^{+t}$ \\
\hline Anti-Smith & - & 40 & $57^{\dagger}$ \\
\hline Anti-phospholipid & - & 44 & 51 \\
\hline Medication usageb (\%) & - & & \\
\hline Prednisone & - & 45 & 55 \\
\hline Mean dose (mg/day) & - & 12.5 & 17.5 \\
\hline Antimalarials & - & 80 & 72 \\
\hline Cytotoxics & - & 28 & $68^{+t}$ \\
\hline Statins & - & 11 & $28^{+}$ \\
\hline Angiotensin-converting enzyme inhibitors & - & 46 & $65^{\dagger}$ \\
\hline
\end{tabular}

aPresence of specific manifestations at any point during the course of disease. bMedication usage at the time of this study. ${ }^{\star} P<0.05$ for systemic lupus erythematosus (SLE) patients with or without lupus nephritis (LN) versus healthy controls. ${ }^{+} P<0.05$ or ${ }^{\dagger+} P<0.001$ for SLE patients with LN versus SLE patients without LN.

tion index calculated by dividing the number of cells that migrated toward MCP-1 by the number of cells that migrated to medium alone.

\section{Measurement of C-reactive protein and complement}

High-sensitivity C-reactive protein, C3 and C4 assays were performed using a BN ProSpec ${ }^{\circledR}$ Nephelometer (Dade Behring, Deerfield, IL, USA) as described elsewhere [16].

\section{In vitro stimulation of healthy donor peripheral blood} mononuclear cells

Peripheral blood mononuclear cells from healthy control individuals were plated on 24 -well plates $\left(10^{6}\right.$ cells/well) in complete medium (DMEM supplemented with $10 \%$ fetal bovine serum, $20 \mathrm{mM} \mathrm{L-glutamine,} 100 \mathrm{lU} / \mathrm{ml}$ penicillin, and $100 \mu \mathrm{g} /$ $\mathrm{ml}$ streptomycin). All cytokines were from BD Bioscience unless indicated otherwise. Cells were incubated for 19 hours at $37^{\circ} \mathrm{C}$ in the presence of recombinant human IFN $\alpha(4 \mathrm{ng} / \mathrm{ml}$; 
PBL Biomedical, Piscataway, NJ, USA), IFN $\gamma$ (2 ng/ml), IL-4 (4 $\mathrm{ng} / \mathrm{ml}), \mathrm{IL}-6$ (4 ng/ml), IL-8 (4 ng/ml), IL-12 (4 ng/ml), or CRP (50 ng/ml; Calbiochem). Flow cytometry was performed immediately after incubation. In some experiments, dexamethasone $\left(10^{-5}\right.$ to $\left.10^{-3} \mathrm{M}\right)$ was added to the culture 3 hours prior to the addition of cytokines.

\section{Statistical analysis}

Differences between disease groups and normal control individuals were evaluated using Student's two-tailed $t$ test unless the data were not normally distributed, in which case the Mann-Whitney $U$ test was used. Correlation coefficients were calculated using Spearman's rank correlation. Data are presented as the mean \pm standard error of the mean. Analyses were performed using Prism software, version 4.0 (GraphPad Software, San Diego, CA, USA). For all analyses, $P<0.05$ was considered significant.

\section{Results}

We assessed the surface expression of Fc $\gamma$ Rs on monocytes from SLE patients with or without $L N$ and from healthy control individuals. Demographics and clinical/laboratory data are summarized in Table 1. There was no difference in the percentage of circulating CD14+ monocytes between SLE patients with or without LN and normal control individuals (Table 2). Absolute monocyte counts, however, were significantly decreased in SLE patients with/without LN when compared with normal control individuals $(268 \pm 29$ cells $/ \mu$ land $254 \pm$ 39 cells $/ \mu \mathrm{l}$, respectively, versus $357 \pm 32$ cells $/ \mu \mathrm{l}$; both $P<$ 0.005 , Student's $t$ test).

\section{Increased Fc $\gamma \mathbf{R I} / \mathbf{C D 6 4}$ expression on SLE monocytes}

In healthy control individuals, nearly all peripheral blood monocytes displayed surface expression of FcyRI/CD64 and Fc $\gamma$ RII/CD32. Only $9.3 \pm 0.7 \%$ of circulating monocytes, however, expressed FcyRIII/CD16 (Figure 1a, top and Table 2). Although circulating monocytes from SLE patients also uniformly expressed Fc $\gamma$ RI/CD64 (Figure 1a, bottom), quantification of FcyRI/CD64 expression showed a significantly higher mean fluorescence intensity in SLE patients compared with healthy control individuals $(521 \pm 21$ versus $319 \pm 22 ; P<$ 0.001 , Student's $t$ test). The expression was even higher in patients with nephritis compared with those without nephritis (567 \pm 28 versus $449 \pm 31 ; P<0.001$, Student's $t$ test) (Figure $1 \mathrm{~b}$ and Table 2).

In contrast, CD32 expression was similar on CD14+ monocytes from SLE patients versus normal healthy control individuals (Figure 1c and Table 2). While the frequencies and absolute numbers of CD16+CD14+ monocytes were similar between SLE patients and control individuals, the intensity of CD16 staining was increased slightly in SLE patients with or without LN (12 \pm 0.4 and $13 \pm 0.6$, respectively, versus control individuals $10 \pm 0.6$; both $P<0.01$, Student's $t$ test) (Fig-

Table 2

Comparison of cell surface marker expression by CD14+ monocytes

\begin{tabular}{|c|c|c|c|}
\hline & Control individuals & SLE patients without LN & SLE patients with LN \\
\hline \multicolumn{4}{|l|}{ CD14+ cells } \\
\hline Percentage $^{a}$ & $4.3 \pm 0.4$ & $3.9 \pm 0.3$ & $4.0 \pm 0.2$ \\
\hline Mean fluorescence intensity & $596.8 \pm 42.9$ & $604.8 \pm 29.9$ & $605.3 \pm 18.7$ \\
\hline Absolute number (cell/ $\mu l)$ & $357.2 \pm 31.5$ & $254.1 \pm 38.5^{\star}$ & $268.3 \pm 29.4^{*}$ \\
\hline \multicolumn{4}{|l|}{ FcyRIII/CD16 } \\
\hline Percentage $^{a}$ & $9.3 \pm 0.7$ & $11.0 \pm 0.6^{\star}$ & $10.8 \pm 0.6$ \\
\hline Mean fluorescence intensity & $10.2 \pm 0.6$ & $13.2 \pm 0.6^{\star \star}$ & $12.5 \pm 0.4^{*}$ \\
\hline Absolute number (cell/ $\mu \mathrm{l})$ & $23.3 \pm 4.1$ & $53.6 \pm 10.0$ & $78.9 \pm 15.7$ \\
\hline \multicolumn{4}{|l|}{ Fc $\gamma \mathrm{RII} / \mathrm{CD} 32$} \\
\hline Percentage $^{a}$ & $87.5 \pm 2.9$ & $85.9 \pm 2.3$ & $81.8 \pm 2.9$ \\
\hline Mean fluorescence intensity & $71.6 \pm 8.3$ & $64.4 \pm 7.5$ & $68.4 \pm 5.9$ \\
\hline Absolute number (cell/ $\mu \mathrm{l})$ & $266.7 \pm 49.2$ & $249.1 \pm 114.5$ & $238.2 \pm 100.9$ \\
\hline \multicolumn{4}{|l|}{ Fc $\gamma \mathrm{RI} / \mathrm{CD} 64$} \\
\hline Percentage $^{a}$ & $99.9 \pm 0.03$ & $99.9 \pm 0.02$ & $99.9 \pm 0.03$ \\
\hline Mean fluorescence intensity & $319.1 \pm 22.2$ & $449.2 \pm 30.5^{\star \star}$ & $567.0 \pm 28.1^{\star \star+t}$ \\
\hline Absolute number (cell/ $\mu \mathrm{l})$ & $352.8 \pm 0.11$ & $252.8 \pm 0.05^{\star}$ & $268.0 \pm 0.08^{*}$ \\
\hline
\end{tabular}

${ }^{\star} P<0.05$ or ${ }^{\star \star} P<0.001$ for systemic lupus erythematosus (SLE) patients with or without lupus nephritis (LN) versus healthy control individuals. ${ }^{+} P<0.05$ or ${ }^{+t} P<0.001$ for SLE patients with LN versus SLE patients without LN. 
(a)
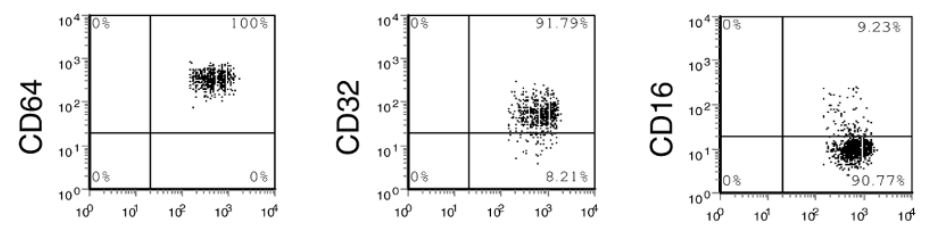

SLE
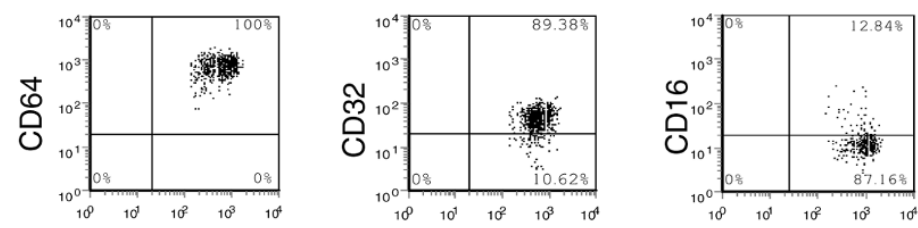

\section{CD14}

(b)

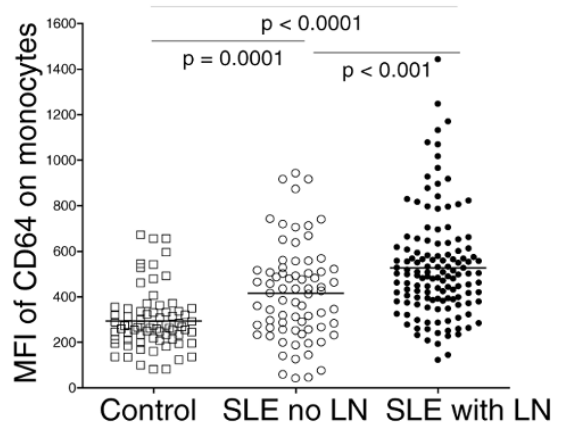

(c)

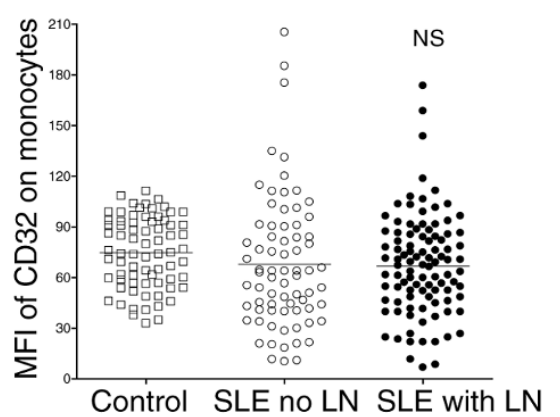

(d)

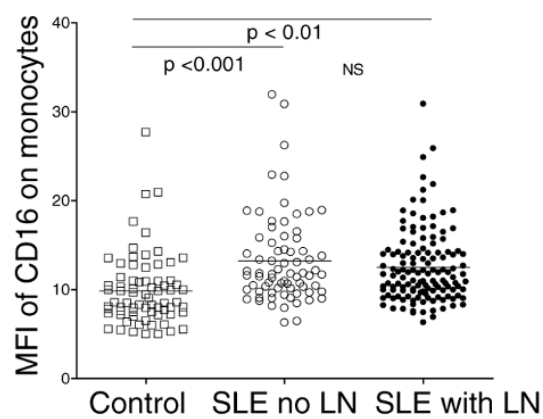

(e)

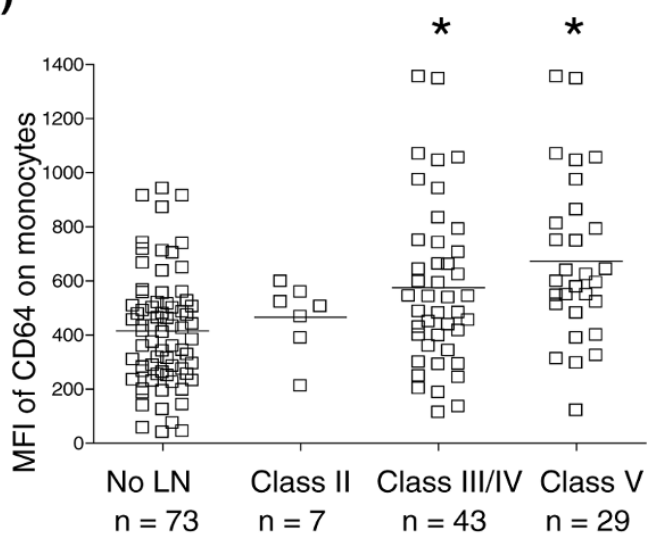

Expression of Fc receptors in healthy control individuals versus systemic lupus erythematosus patients. (a) Representative scattergrams of

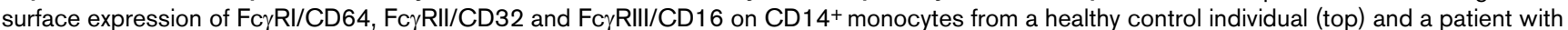
systemic lupus erythematosus (SLE) (bottom). CD14+ monocytes were gated based on their forward/sideward scatter. (b-d) Expression of FcyRl/

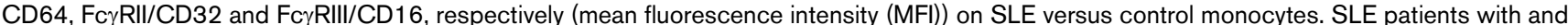
without lupus nephritis $(\mathrm{LN})$ are analyzed separately. Differences between groups were compared by Student's $t$ test. (e) Comparison of Fc $\gamma \mathrm{RI} /$ CD64 expression (MFI) on monocytes from SLE patients without LN or with biopsy-proven World Health Organization class II, class III/IV, or class V LN. ${ }^{*} P<0.05$ compared with SLE patients without LN (Student's $t$ test). 
ure $1 \mathrm{~d}$ and Table 2). We also assessed the expression of HLA$\mathrm{DR}$ and $\mathrm{CD} 62 \mathrm{~L}$, markers related to monocyte activation, but found no significant differences between the groups (data not shown).

To further evaluate the relationship between Fc $\gamma \mathrm{R}$ expression and LN, we analyzed the expression of Fc $\gamma$ Rs on monocytes in 79 patients who had undergone renal biopsy (class II, $n=7$; class III/IV, $n=43$; and class $V, n=29$ ). The presence of class III/IV or class V LN, but not of class II LN, was associated with increased expression of FcyRI/CD64 compared with SLE patients who did not have LN (Figure 1e). In contrast, the expression of Fc $\gamma$ RII and Fc $\gamma$ RIII was similar among the different classes of LN (data not shown).

\section{Increased Fc $\gamma$ RI/CD64 expression is associated with impaired renal function}

Since FcyRI/CD64 expression on monocytes was greater in SLE patients with LN compared with SLE patients without LN, we investigated its relationship with individual markers of renal involvement. Increased expression of FcyRI/CD64 on monocytes correlated positively with elevated creatinine $\left(r^{2}=0.27\right.$, $P<0.001$; Spearman's correlation) (Figure 2a, left) and blood urea nitrogen levels $\left(r^{2}=0.12, P=0.001\right.$; Spearman's correlation) (Figure $2 \mathrm{a}$, middle), as well as with the degree of proteinuria (microalbumin/creatinine ratio, $r^{2}=0.10, P<0.001$; Spearman's correlation) (Figure 2a, right).

\section{Increased levels of Fc $\gamma \mathbf{R I / C D 6 4}$ expression are associated with ongoing inflammation}

We next examined the relationship of Fc $\gamma \mathrm{RI} / \mathrm{CD} 64$ expression with measures of systemic inflammation such as high-sensitivity CRP and complement C3 [17]. In patients with SLE, the expression of Fc $\gamma \mathrm{RI} / \mathrm{CD} 64$ on monocytes was positively correlated with elevated serum levels of high-sensitivity CRP $\left(r^{2}=\right.$ $0.14, P<0.0001$; Spearman's correlation) (Figure 2b). Fc $\gamma \mathrm{RI} /$ CD64 expression showed an inverse relationship with serum C3 ( $r^{2}=0.07, P<0.0001$; Spearman's correlation) (Figure 2c) but not with $\mathrm{C} 4\left(r^{2}=0.01, P=0.14\right)$ (data not shown). Increased Fc $\gamma \mathrm{RI} / \mathrm{CD} 64$ expression was also associated with anti-dsDNA autoantibodies (534.1 \pm 21.4 versus $426.5 \pm$ 21.0 mean fluorescence intensity units, $P=0.0005$ ) (Figure 2d). Increased FcyRI/CD64 surface expression on monocytes was therefore associated with impaired renal function, antidsDNA autoantibody production, C3 consumption, and ongoing inflammation in SLE patients.

\section{Fc $\gamma$ RI/CD6hi monocytes have an activated phenotype}

Monocyte migration to the kidneys and the subsequent release of inflammatory mediators are thought to be critical steps initiating renal damage $[18,19]$. We evaluated the migratory capacity of circulating monocytes from SLE patients using an in vitro transwell assay, and found that monocytes with elevated FcyRI/CD64 expression exhibited increased migration toward the chemokine MCP-1 $\left(r^{2}=0.09, P=0.005\right.$; Spearman's correlation) (Figure 3a).

As monocyte-derived proinflammatory cytokines and chemokines such as MCP-1 regulate immune cell infiltration and play an important role in organ damage in SLE [20], we examined the ability of $\mathrm{CD} 64^{+}$monocytes to produce MCP-1. After LPS stimulation, monocytes with high FcyRI/CD64 expression produced higher levels of the chemokine than CD64- monocytes, as measured by intracellular staining $\left(r^{2}=0.09, P<0.001\right.$; Spearman's correlation) (Figure 3b).

Since the binding of CRP to Fc $\gamma$ RI/CD64 and Fc $\gamma$ Rlla/CD32a can lead to increased inflammatory cytokine production [2123], we stimulated monocytes from SLE patients with CRP (50 $\mathrm{ng} / \mathrm{ml}$ ) and analyzed the MCP-1 production. CRP and LPS elicited similar levels of intracellular MCP-1 staining (compare Figure $3 \mathrm{~b}$ and Figure $3 \mathrm{c}$ ). Consistent with the results with LPS stimulation, high Fc $\gamma \mathrm{RI} / \mathrm{CD} 64$ surface expression was associated with increased intracellular MCP-1 production in response to CRP ( $r^{2}=0.26, P=0.03$; Spearman's correlation) (Figure 3c). Monocytes with elevated surface expression of Fc $\gamma \mathrm{RI} / \mathrm{CD} 64$ therefore displayed a more activated phenotype in terms of migratory properties and MCP-1 production in response to either LPS or CRP.

\section{Medication effects on Fc $\gamma$ RI/CD64 expression}

Corticosteroids potently downmodulate certain inflammatory markers on circulating monocytes [24]. Since about one-half of our SLE patients were treated with corticosteroids (Table 1), we asked whether the levels of Fc $\gamma \mathrm{RI} / \mathrm{CD} 64$ expression by monocytes were affected by treatment. When analyzed as a group, patients treated with conventional doses of prednisone ( $<40 \mathrm{mg} /$ day) showed no difference in FcyRI/CD64 expression compared with those patients not treated with corticosteroids (Figure 4a). There also was no apparent effect of antimalarial, cytotoxic or statin therapy on the expression of Fc $\gamma$ Rs (Figure 4a). Stratifying patients based on the prednisone dose revealed that a daily dosage $\geq 40 \mathrm{mg}$ was associated with decreased $\mathrm{Fc} \gamma \mathrm{RI} / \mathrm{CD} 64$ expression on monocytes (Figure 4b). A similar trend (not statistically significant) was seen at a dose of 20 to $30 \mathrm{mg} /$ day. This effect was not seen at lower dosages (Figure 4b). Patients treated with $\geq 40 \mathrm{mg} /$ day prednisone tended to display lower serum levels of $\mathrm{C} 3$ $(67.6 \pm 8.5$ versus $93.7 \pm 3.4 \mathrm{mg} / \mathrm{dl} ; P<0.05)$ and higher levels of blood urea nitrogen (36.9 \pm 9.0 versus $15.6 \pm 0.8 \mathrm{ng} /$ $\mathrm{dl} ; P<0.05)$ compared with their counterparts given lower doses, consistent with higher disease activity (data not shown). There was no difference in Systemic Lupus Erythematosus Disease Activity Index scores, American College of Rheumatology criteria counts, serum creatinine, high-sensitivity CRP levels, or microalbumin/creatinine ratios between the groups (data not shown). 
(a)
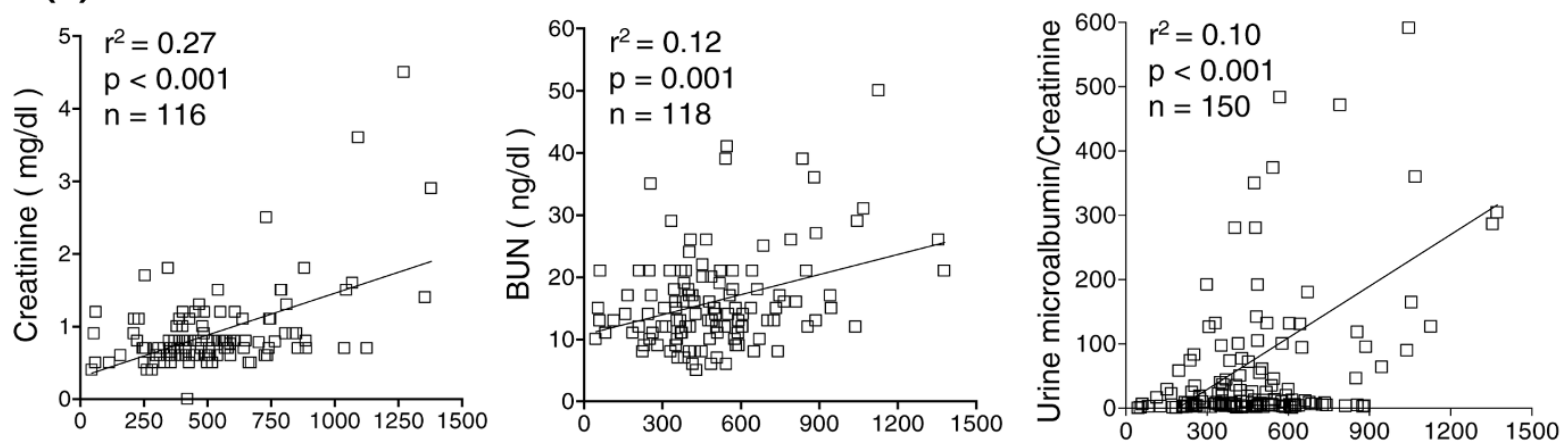

$\mathrm{MFI}$ of CD64 on monocytes

(b)

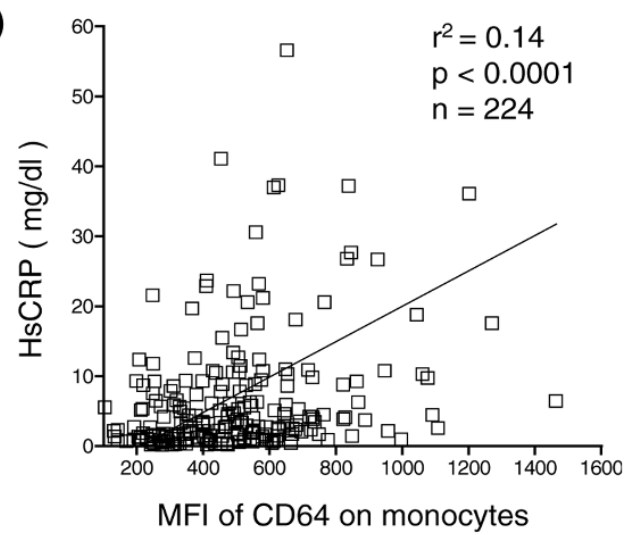

(c)

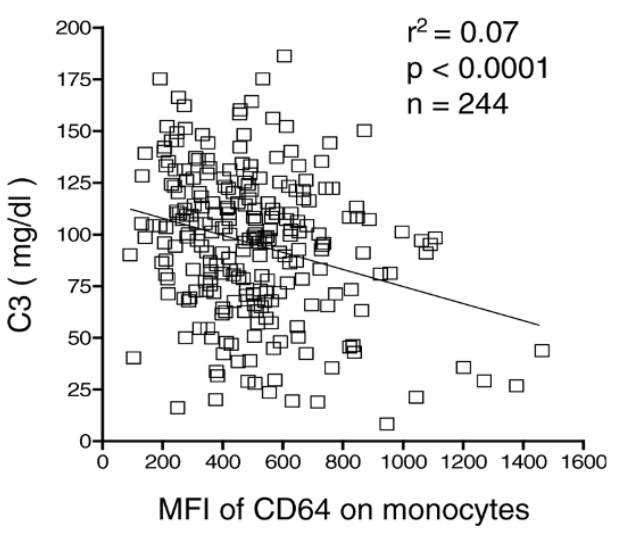

(d)

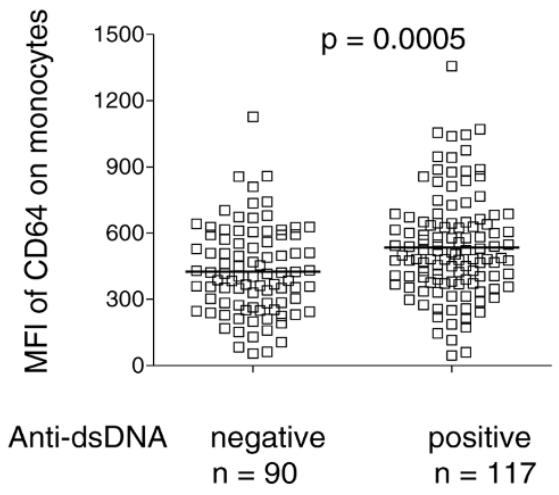

Fc $\gamma$ RI/CD64 expression on monocytes correlates with renal disease, C-reactive protein, and complement C3 levels. (a) FcyRI/CD64 expression levels on circulating monocytes from systemic lupus erythematosus (SLE) patients (both lupus nephritis (LN) and non-LN patients) correlated with increased serum creatinine (left) and blood urea nitrogen (BUN) (middle), as well as with proteinuria (microalbumin/creatinine ratio) (right). MFI, mean fluorescence intensity. Expression of FcyRI/CD64 correlated (b) positively with serum high-sensitivity C-reactive protein (HsCRP) levels and (c) negatively with serum C3 levels (Spearman's correlation). (d) Comparison of Fc $\gamma R$ I/CD64 expression in SLE patients positive or negative for antidsDNA autoantibodies (Student's $t$ test). 


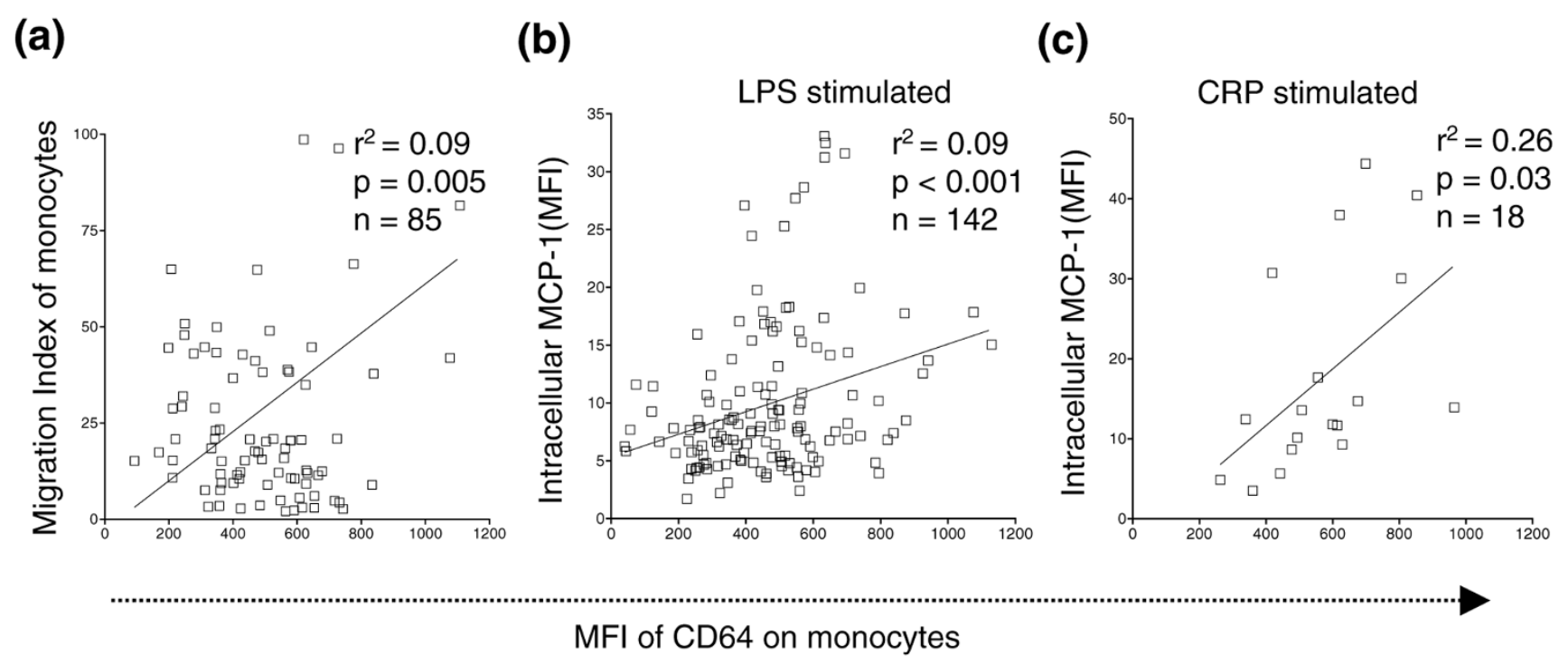

Fc $\gamma$ RI/CD64hi monocytes have an activated phenotype. (a) Correlation between FcyRl/CD64 expression levels and monocyte migration toward monocyte chemotractic protein 1 (MCP-1) (transwell assay, systemic lupus erythematosus (SLE) patients). (b) Correlation of elevated Fc $\gamma R$ RI/CD64 expression on monocytes with an increased capacity to produce MCP-1, as measured by intracellular staining of CD14+ monocytes 4 hours after lipopolysaccharide (LPS) stimulation. MFI, mean fluorescence intensity. (c) Correlation of FcyRI/CD64 expression with levels of MCP-1 production by monocytes following C-reactive protein (CRP) stimulation for 4 hours.

\section{Effect of cytokines on Fc $\gamma$ RI/CD64 expression}

Several studies have shown that the expression of FcyRI/ CD64 can be influenced by different cytokines in pathogenic circumstances. Dysregulation of proinflammatory cytokine production has also been well documented in SLE. To examine potential inducers of Fc $\gamma \mathrm{RI} / \mathrm{CD} 64$ upregulation, we stimulated peripheral blood mononuclear cells from healthy control individuals with a panel of cytokines. Overnight incubation with IFN $\alpha$, IFN $\gamma$, and IL-12 significantly increased FC $\gamma$ RI/CD64 expression on monocytes, whereas IL-6, IL-8, IL-10, TNF $\alpha$, and CRP treatment did not (Figure $5 \mathrm{a}$ ). Similar results were obtained when the experiment was performed using cultured THP-1 cells (data not shown).

Curiously, while the addition of dexamethasone to whole blood did not alter the steady-state levels of Fc $\gamma \mathrm{RI} / \mathrm{CD} 64$ expression on monocytes in vitro (Figure $5 \mathrm{~b}$ ), high concentrations of dexamethasone $\left(\geq 10^{-4} \mathrm{M}\right)$ inhibited the upregulation of $\mathrm{Fc} \gamma \mathrm{R} 1 /$ CD64 expression induced by IFN $\gamma$, IFN $\alpha$ and IL-12 (Figure $5 c)$. This effect was not seen with lower concentrations of dexamethasone.

\section{Discussion}

In mouse models of SLE, monocytes/macrophages bearing activating Fc receptors are pivotal to the development of ICmediated glomerulonephritis $[25,26]$. There is indirect evidence that the same may be true of human lupus $[27,28]$, although the relationship between activating $\mathrm{F}_{\mathrm{c}} \gamma \mathrm{R}$ expression and the pathogenesis of human $\mathrm{LN}$ is less clear than in the mouse. In the present study, we examined Fc $\gamma$ R expression in more than 200 SLE patients. The levels of FcyRI/CD64 expression on circulating monocytes were significantly elevated in SLE patients, especially in those with LN. Increased monocyte $\mathrm{Fc} \gamma \mathrm{RI} / \mathrm{CD} 64$ expression also was associated with markers of impaired renal function impairment and with a greater ability to migrate and secrete the chemokine MCP-1.

The proinflammatory role of activating $\mathrm{Fc} \gamma \mathrm{R}$ in $\mathrm{LN}$ is evident in mice deficient in FcyRI/III, which are protected from the development of renal disease despite the presence of glomerular IC deposits [10]. A recent study showed that the expression of $\mathrm{Fc} \gamma \mathrm{RI} / \mathrm{II}$ by monocytes was both necessary and sufficient to trigger nephritis in NZB/W F1 mice [26]. In contrast, the inhibitory Fc $\gamma$ Rllb suppresses inflammation and spontaneous activation of autoreactive lymphocytes and autoantibody production in mice $[26,29]$.

In human SLE, several groups have shown the abnormal upregulation of activating $\mathrm{Fc} \gamma$ receptors on monocytes $[13,30]$. One relatively small study, however, found no significant difference in $\mathrm{FC} \gamma \mathrm{RI} / \mathrm{CD} 64$ or Fc $\gamma \mathrm{RIII} / \mathrm{CD} 16$ expression on SLE monocytes compared with healthy controls [31]. About two-thirds of the patients studied here had elevated levels of monocyte surface CD64 in the present study, a discrepancy that may be due to the relatively small number of subjects studied previously. Consistent with the observations of others $[13,28]$, our data show that the activating receptor Fc $\gamma$ RIII/ CD16 also is upregulated in SLE patients compared with 
(a)
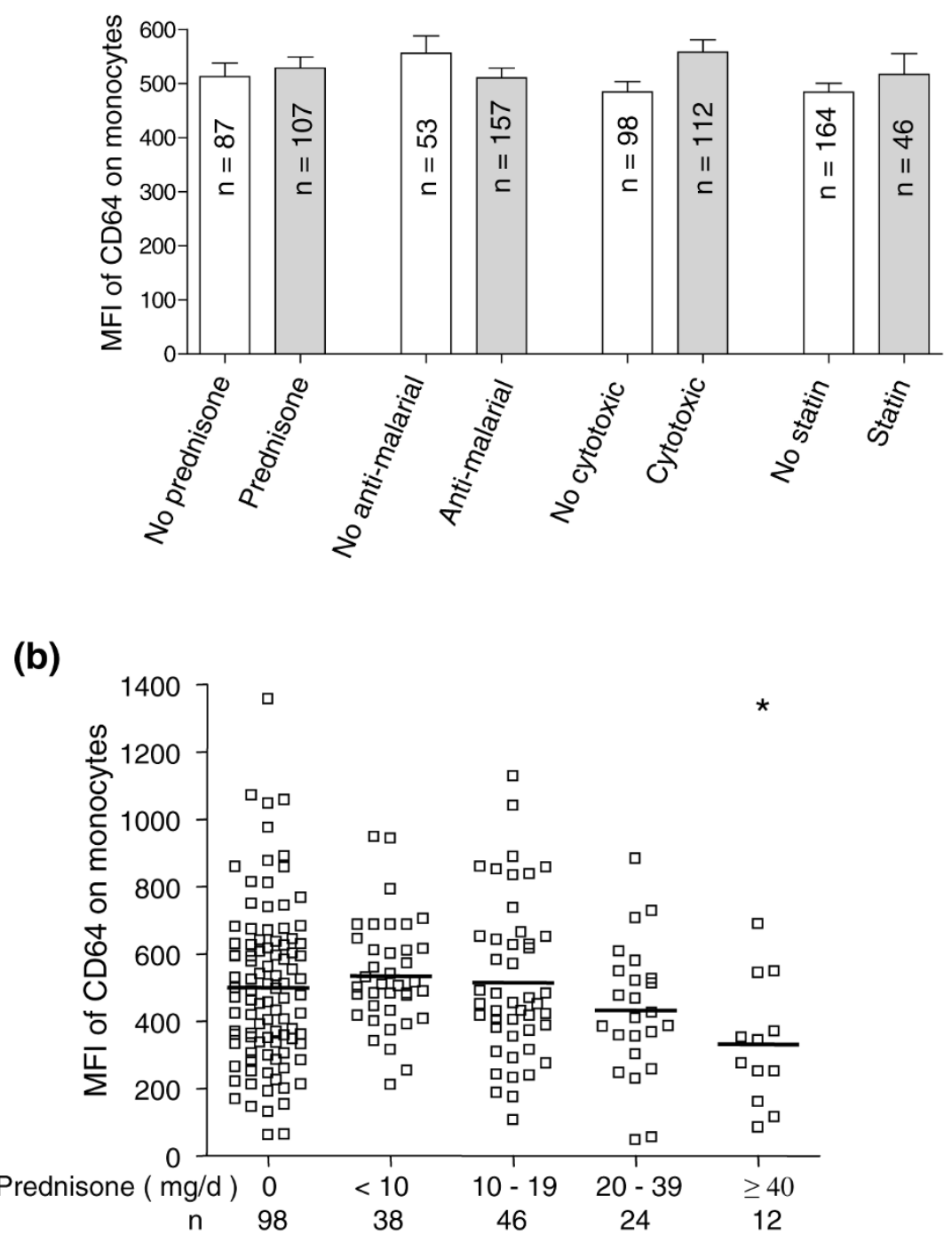

Effect of medications and cytokines on Fc $\gamma$ RI/CD64 expression by circulating monocytes. (a) Comparison of Fc $\gamma \mathrm{RI} / \mathrm{CD} 64$ expression on monocytes between systemic lupus erythematosus (SLE) patients receiving or not receiving prednisone, antimalarials, cytotoxic drugs, or statins. $\mathrm{MFI}$, mean fluorescence intensity. (b) Relationship between daily corticosteroid dose and monocyte Fc $\gamma \mathrm{RI} / \mathrm{CD} 64$ expression in SLE patients. ${ }^{*} P<$ 0.05 compared with SLE patients not receiving steroid treatment.

healthy control individuals. In line with murine lupus data, our data support the idea that activating Fc $\gamma$ Rs play a crucial role in IC-mediated organ damage in SLE.

Although NZB/W F1 mice deficient in activating Fc $\gamma$ Rs are protected from renal disease, the relative contributions of the individual activating $\mathrm{Fc} \gamma \mathrm{Rs}$ have not been studied further. Our data show that although both Fc $\gamma$ RIII/CD16 and Fc $\gamma$ RI/CD64 expression were elevated, increased Fc $\gamma$ RIII/CD16 expression was not associated with $\mathrm{LN}$, suggesting that activation via Fc $\gamma$ RI/CD64 may be more significant to the pathogenesis of human LN. Moreover, we found no difference in the surface expression of FcyRII/CD32 on monocytes between the SLE patients and healthy control individuals, although interpretation of this finding is limited by the inability of the anti-CD32 antibody to distinguish the activating FcyRlla and inhibitory FcyRllb. Expression of the inhibitory FcyRllb in peripheral blood mononuclear cells from SLE patients has been recently studied using specific antibodies [32]. While low expression levels were found on B-lymphocyte subsets, FcyRllb/CD32b expression was not impaired on monocytes from SLE patients.

The importance of FcyRs in the pathogenesis of SLE is further illustrated by extensive polymorphism studies involving Fc $\gamma \mathrm{RII} /$ 
(a)

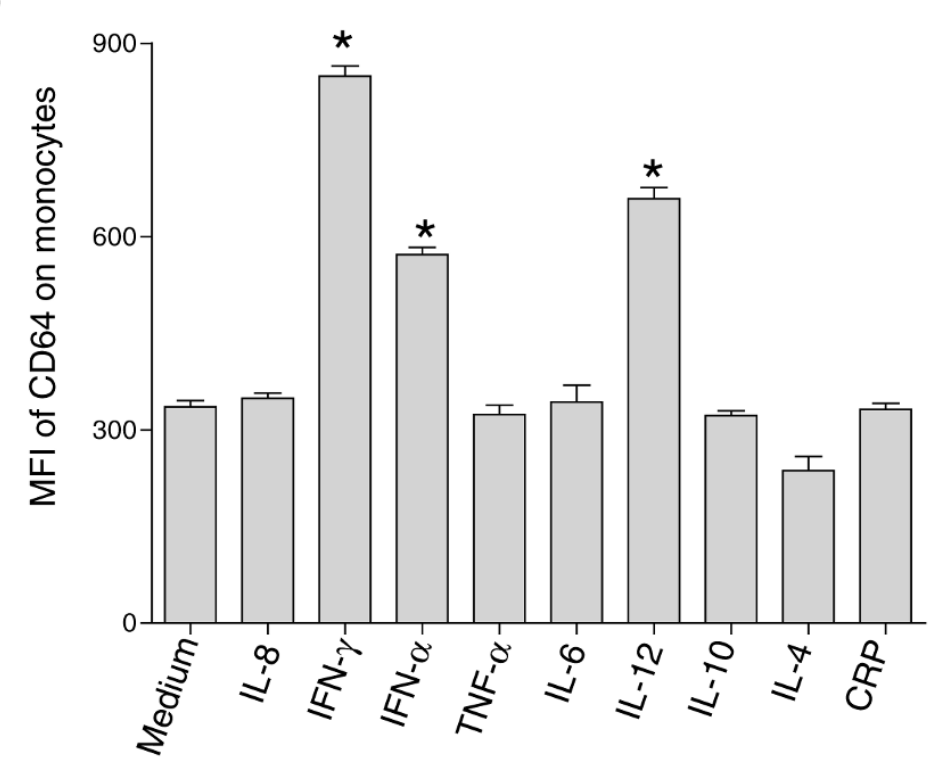

(b)

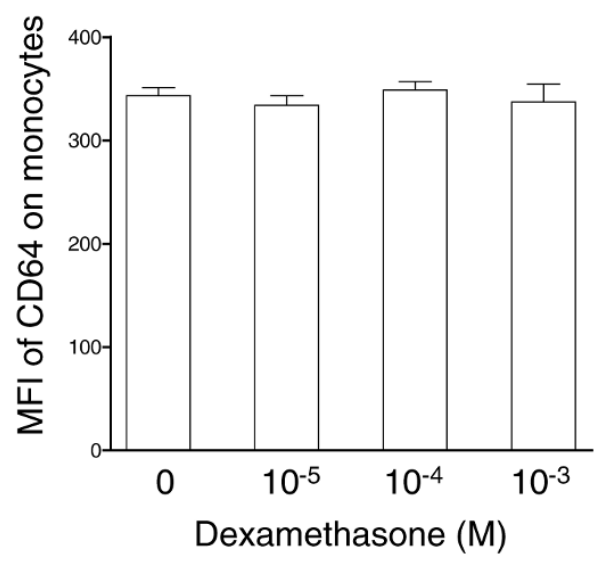

(c)

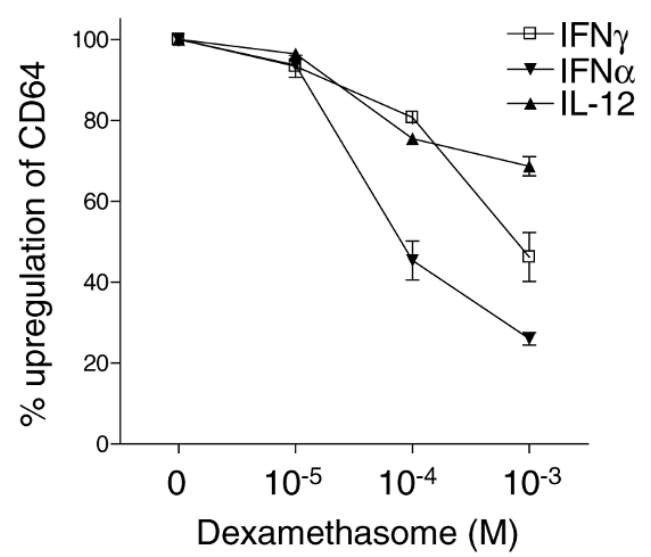

Effect of cytokines and dexamethasone on Fc $\gamma \mathrm{RI} / \mathrm{CD} 64$ expression in vitro. (a) Direct effects of cytokines and C-reactive protein (CRP) on $\mathrm{Fc \gamma RI/CD64}$ expression on circulating monocytes. Peripheral blood mononuclear cells from healthy subjects were cultured with recombinant IFN $\alpha$ (4 ng/ml), IFN $\gamma(2 \mathrm{ng} / \mathrm{ml}), \mathrm{IL}-4$ (4 ng/ml), IL-6 (4 ng/ml), IL-8 (4 ng/ml), IL-12 (4 ng/ml) or CRP (50 ng/ml) for 19 hours in vitro. FcyRl/CD64 expression (mean fluorescence intensity (MFI)) was analyzed by flow cytometry. Values represent the mean \pm standard error of the mean (SEM) from five independent experiments. ${ }^{*} P<0.001$ compared with medium alone. (b) Effect of dexamethasone on monocyte FcyRI/CD64 expression in vitro. Values represent the mean \pm SEM from three independent experiments. (c) Effect of dexamethasone on the upregulation of FcyRI/CD64 by IFN $\alpha$, IFN $\gamma$, and IL-12. Values represent the mean \pm SEM from two independent experiments.

CD32 and Fc $\gamma R$ IIIICD16. Several of these polymorphisms -

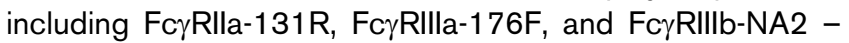
have been associated with lupus susceptibility [33,34]. Importantly, some of them cause functional alterations of the inhibitory receptor $[35,36]$ while others are associated with reduced surface expression of Fc $\gamma$ Rllb on both memory and plasma B lymphocytes [37]. To our knowledge, however, polymorphisms involving Fc $\gamma \mathrm{RI} / \mathrm{CD} 64$ have not been linked to SLE.
The markedly elevated expression of Fc $\gamma R \mathrm{RI}$ /CD64 among SLE patients with LN (Figure 1b) may serve as a surrogate marker of renal disease that correlates with both established measures of renal dysfunction (increased serum creatinine, blood urea nitrogen, and proteinuria) and inflammation (elevated serum CRP, C3 deficiency). Monocyte Fc $\gamma$ RI/CD64 expression, however, did not correlate with overall disease activity as assessed by the Systemic Lupus Erythematosus Disease Activity Index (data not shown). This was not due to medication use, since FcyRI/CD64 levels on circulating monocytes were unaffected by treatment with prednisone at doses $<40$ 
$\mathrm{mg} /$ day, or by antimalarials, cytotoxic agents, or statins. In contrast, higher doses of prednisone ( $\geq 40 \mathrm{mg} /$ day) or dexamethasone treatment in vitro reduced $\mathrm{Fc \gamma RI/CD64}$ expression, possibly due to direct effects on proinflammatory cytokine production $[38,39]$ or to the generation of a subset of anti-inflammatory monocytes that secrete IL-10 $[40,41]$.

Our in vitro data suggest that IL-12, IFN $\gamma$, and IFN $\alpha$ are potential inducers of FcyRI/CD64 expression in SLE. Interestingly, excess production of all three of these cytokines promotes LN in mice [42-44]. In human LN, increased levels of IFN $\gamma, \mathrm{IL}-12$ and IFN $\alpha / \beta$ are found in the kidney $[45,46]$. Dysregulation of IFN $\alpha$ production is also associated with renal involvement [47]. Our data are consistent with the possibility that the overproduction of one or more of these cytokines promotes $L N$ by enhancing the recruitment of proinflammatory $\left(\mathrm{CD} 64^{+}\right)$monocytes/macrophages to the renal glomerulus. Although there was a highly significant correlation between FcyRl/CD64 expression and several markers of renal involvement or inflammation (Figure 2), the $r^{2}$ values were in some cases relatively low. This indicated the existence of additional variables, at present undefined, affecting Fc $\gamma \mathrm{RI} / \mathrm{CD} 64$ expression. Elucidating the variables that affect Fc $\gamma \mathrm{RI} / \mathrm{CD} 64$ expression, perhaps including serum levels of the cytokines examined in our in vitro studies, will require further study.

FcyRl/CD64 plays a role in phagocytosis, cytolysis, degranulation, and induction of inflammatory cytokines. Additionally, FcyRl-deficient mice display defective peritoneal monocyte infiltration in response to ICs [48]. Consistent with these studies, our data demonstrated that circulating human monocytes from patients with upregulated Fc $\gamma \mathrm{RI} / \mathrm{CD} 64$ expression exhibited increased migratory capacity and MCP-1 production in response to LPS or CRP stimulation. Monocyte/macrophage infiltration is important in promoting mesangial hypercellularity and the development of glomerulosclerosis in both human and animal models $[49,50]$. Additionally, the number of infiltrating monocytes/macrophages is associated with more severe renal injury and poor prognosis in LN [50,51].

As seen in animal models $[10,26,52]$, monocytes expressing FcyRl/CD64 may be important to the pathogenesis of ICmediated nephritis in SLE. Elevated production of IFN $\alpha$ and IFN $\gamma$ in SLE may induce the expression of Fc $\gamma \mathrm{RI} / \mathrm{CD} 64$ monocytes and facilitate the infiltration of these cells to the sites of IC deposition in the kidney [48]. Since IFN $\alpha$ and IFN $\gamma$ also stimulate the production of monocyte attractants such as MCP-1, the presence of these cytokines in the kidney also may promote the influx of monocytes. In turn, signal transduction downstream of $\mathrm{Fc} \gamma \mathrm{RI} / \mathrm{CD} 64$ leads to monocyte activation and further production of inflammatory cytokines and chemokines. These events could culminate in a vicious cycle of renal inflammation and monocyte infiltration, ultimately leading to permanent tissue damage.

\section{Conclusion}

Our study demonstrates that elevated surface expression of Fc $\gamma \mathrm{RI} / \mathrm{CD} 64$ is associated with ongoing systemic inflammation and renal disease in lupus patients. We propose that upregulation of Fc $\gamma \mathrm{RI} / \mathrm{CD} 64$ expression on circulating monocytes may be a useful surrogate marker of monocyte activation in SLE.

\section{Competing interests}

The authors declare that they have no competing interests.

\section{Authors' contributions}

WHR and HBR contributed equally to this work. YL carried out data analysis and interpretation, and the study design, and assisted in manuscript preparation. PYL participated in date analysis and interpretation, and assisted in manuscript preparation. ESS participated in acquisition of data and patient recruitment. $\mathrm{SN}$ participated in statistical analysis. MS assisted in data interpretation. MSS participated in acquisition of data and patient recruitment. WHR carried out the study design and data interpretation, and assisted in patient recruitment and preparation of the manuscript. HBR conceived of the study and coordinated patient recruitment, data analysis and preparation of the manuscript. All authors read and approved the final manuscript.

\section{Acknowledgements}

The present work was supported by grants from the National Institutes of Health (K08 DK02890 and MO1 RR00082) and the Greater Florida Chapter of the Lupus Foundation of America and the Lupus Research Institute (New York, USA). PYL is an NIH T32 trainee (DK07518). The authors thank Marlene Sarmiento, Annie Chan, Frances Reeves, Ashley Armstrong, Emily Naglich, Kate Brunner and UF GCRC staff for clinical assistance; and Barbara Kolheffer, Christopher Kennedy and Ed Butfiloski for technical assistance.

\section{References}

1. Reeves $\mathrm{WH}$, Narain $\mathrm{S}$, Satoh $\mathrm{M}$ : Autoantibodies in systemic lupus erythematosus. In Arthritis and Allied Conditions Edited by: Koopman WJ, Moreland LW. Philadelphia, PA: Lippincott Williams \& Wilkins; 2004:1497-1521.

2. Lukacs K, Kavai M, Banyai A, Sonkoly I, Vegh E, Szabo G, Szegedi $\mathrm{G}$ : Effects of immune complexes from SLE patients on human monocyte locomotion and Fc receptor function. Ann Rheum Dis 1984, 43:729-733.

3. McLigeyo SO: Pathogenesis of lupus nephritis: a review. East Afr Med J 1998, 75:628-631.

4. Rovin BH, Song H, Birmingham DJ, Hebert LA, Yu CY, Nagaraja $\mathrm{HN}$ : Urine chemokines as biomarkers of human systemic lupus erythematosus activity. J Am Soc Nephrol 2005 , 16:467-473.

5. Li Y, Tucci M, Narain S, Barnes EV, Sobel ES, Segal MS, Richards HB: Urinary biomarkers in lupus nephritis. Autoimmun Rev 2006, 5:383-388.

6. Salmon JE, Pricop L: Human receptors for immunoglobulin G: key elements in the pathogenesis of rheumatic disease. Arthritis Rheum 2001, 44:739-750.

7. Ziegler-Heitbrock L: The CD14+CD16+ blood monocytes: their role in infection and inflammation. J Leukoc Biol 2007, 81:584-592.

8. Pricop L, Redecha P, Teillaud JL, Frey J, Fridman WH, Sautes-Fridman C, Salmon JE: Differential modulation of stimulatory and inhibitory Fc $\gamma$ receptors on human monocytes by Th1 and Th2 cytokines. J Immunol 2001, 166:531-537. 
9. Ravetch JV, Bolland S: IgG Fc receptors. Annu Rev Immunol 2001, 19:275-290.

10. Clynes R, Dumitru C, Ravetch JV: Uncoupling of immune complex formation and kidney damage in autoimmune glomerulonephritis. Science 1998, 279:1052-1054.

11. Muller Kobold AC, Kallenberg CG, Tervaert JW: Monocyte activation in patients with Wegener's granulomatosis. Ann Rheum Dis 1999, 58:237-245.

12. Wijngaarden $S$, van Roon JA, Bijlsma JW, Winkel JG van de, Lafeber FP: Fcy receptor expression levels on monocytes are elevated in rheumatoid arthritis patients with high erythrocyte sedimentation rate who do not use anti-rheumatic drugs. Rheumatology (Oxford) 2003, 42:681-688.

13. Fries LF, Mullins WW, Cho KR, Plotz PH, Frank MM: Monocyte receptors for the Fc portion of IgG are increased in systemic lupus erythematosus. J Immunol 1984, 132:695-700.

14. Tan EM, Cohen AS, Fries JF, Masi AT, McShane DJ, Rothfield NF, Schaller JG, Talal N, Winchester RJ: The 1982 revised criteria for the classification of systemic lupus erythematosus. Arthritis Rheum 1982, 25:1271-1277.

15. Bombardier C, Gladman DD, Urowitz MB, Caron D, Chang $\mathrm{CH}$ : Derivation of the SLEDAI. A disease activity index for lupus patients. The Committee on Prognosis Studies in SLE. Arthritis Rheum 1992, 35:630-640.

16. Barnes EV, Narain S, Naranjo A, Shuster J, Segal MS, Sobel ES, Armstrong AE, Santiago BE, Reeves WH, Richards HB: High sensitivity C-reactive protein in systemic lupus erythematosus: relation to disease activity, clinical presentation and implications for cardiovascular risk. Lupus 2005, 14:576-582.

17. Sjowall C, Bengtsson AA, Sturfelt G, Skogh T: Serum levels of autoantibodies against monomeric $C$-reactive protein are correlated with disease activity in systemic lupus erythematosus. Arthritis Res Ther 2004, 6:R87-R94.

18. Lloyd CM, Minto AW, Dorf ME, Proudfoot A, Wells TN, Salant DJ, Gutierrez-Ramos JC: RANTES and monocyte chemoattractant protein-1 (MCP-1) play an important role in the inflammatory phase of crescentic nephritis, but only MCP-1 is involved in crescent formation and interstitial fibrosis. J Exp Med 1997, 185:1371-1380.

19. Kelley VR: Leukocyte-renal epithelial cell interactions regulate lupus nephritis. Semin Nephro/ 2007, 27:59-68.

20. Tucci M, Barnes EV, Sobel ES, Croker BP, Segal MS, Reeves WH, Richards HB: Strong association of a functional polymorphism in the monocyte chemoattractant protein 1 promoter gene with lupus nephritis. Arthritis Rheum 2004, 50:1842-1849.

21. Marnell L, Mold C, Du Clos TW: C-reactive protein: ligands, receptors and role in inflammation. Clin Immunol 2005, 117:104-111.

22. Bang R, Marnell L, Mold C, Stein MP, Clos KT, Chivington-Buck C, Clos TW: Analysis of binding sites in human $\mathrm{C}$-reactive protein for Fc\{ \{\} RI, Fc $\{\gamma\}$ RIIA, and C1q by site-directed mutagenesis. J Biol Chem 2005, 280:25095-25102.

23. Tron K, Manolov DE, Rocker C, Kachele M, Torzewski J, Nienhaus GU: C-reactive protein specifically binds to $\mathrm{Fc} \gamma$ receptor type I on a macrophage-like cell line. Eur J Immunol 2008, 38:1414-1422

24. Sumegi A, Antal-Szalmas $P$, Aleksza M, Kovacs I, Sipka S, Zeher M, Kiss E, Szegedi G: Glucocorticosteroid therapy decreases CD14-expression and CD14-mediated LPS-binding and activation of monocytes in patients suffering from systemic lupus erythematosus. Clin Immunol 2005, 117:271-279.

25. Park SY, Ueda S, Ohno H, Hamano $Y$, Tanaka M, Shiratori T, Yamazaki T, Arase H, Arase N, Karasawa A, Sato S, Ledermann B, Kondo Y, Okumura K, Ra C, Saito T: Resistance of Fc receptordeficient mice to fatal glomerulonephritis. J Clin Invest 1998, 102:1229-1238.

26. Bergtold A, Gavhane A, D'Agati V, Madaio M, Clynes R: FcR-bearing myeloid cells are responsible for triggering murine lupus nephritis. J Immunol 2006, 177:7287-7295.

27. Parris TM, Kimberly RP, Inman RD, McDougal JS, Gibofsky A, Christian CL: Defective Fc receptor-mediated function of the mononuclear phagocyte system in lupus nephritis. Ann Intern Med 1982, 97:526-532.

28. Salmon JE, Millard S, Schachter LA, Arnett FC, Ginzler EM, Gourley MF, Ramsey-Goldman R, Peterson MG, Kimberly RP: Fc $\gamma$ RIIA alleles are heritable risk factors for lupus nephritis in African Americans. J Clin Invest 1996, 97:1348-1354.
29. Lin $Q$, Xiu $Y$, Jiang $Y$, Tsurui $H$, Nakamura $K$, Kodera $S$, Ohtsuji $M$, Ohtsuji N, Shiroiwa W, Tsukamoto K, Amano H, Amano E, Kinoshita K, Sudo K, Nishimura H, Izui S, Shirai T, Hirose S: Genetic dissection of the effects of stimulatory and inhibitory IgG Fc receptors on murine lupus. J Immunol 2006, 177:1646-1654.

30. Salmon JE, Kimberly RP, Gibofsky A, Fotino M: Defective mononuclear phagocyte function in systemic lupus erythematosus: dissociation of Fc receptor-ligand binding and internalization. $J$ Immunol 1984, 133:2525-2531.

31. Hepburn AL, Mason JC, Davies KA: Expression of Fc $\gamma$ and complement receptors on peripheral blood monocytes in systemic lupus erythematosus and rheumatoid arthritis. Rheumatology (Oxford) 2004, 43:547-554.

32. Mackay M, Stanevsky A, Wang T, Aranow C, Li M, Koenig S, Ravetch JV, Diamond B: Selective dysregulation of the FcrllB receptor on memory B cells in SLE. J Exp Med 2006, 203:2157-2164

33. Dijstelbloem HM, Bijl M, Fijnheer R, Scheepers RH, Oost WW, Jansen MD, Sluiter WJ, Limburg PC, Derksen RH, Winkel JG van de, Kallenberg CG: Fc $\gamma$ receptor polymorphisms in systemic lupus erythematosus: association with disease and in vivo clearance of immune complexes. Arthritis Rheum 2000 43:2793-2800.

34. Brown EE, Edberg JC, Kimberly RP: Fc receptor genes and the systemic lupus erythematosus diathesis. Autoimmunity 2007, 40:567-581.

35. Li X, Wu J, Carter RH, Edberg JC, Su K, Cooper GS, Kimberly RP: A novel polymorphism in the Fc $\gamma$ receptor IIB (CD32B) transmembrane region alters receptor signaling. Arthritis Rheum 2003, 48:3242-3252

36. Floto RA, Clatworthy MR, Heilbronn KR, Rosner DR, MacAry PA, Rankin A, Lehner PJ, Ouwehand WH, Allen JM, Watkins NA, Smith KG: Loss of function of a lupus-associated Fc $\gamma$ RIllb polymorphism through exclusion from lipid rafts. Nat Med 2005, 11:1056-1058.

37. Su K, Yang H, Li X, Gibson AW, Cafardi JM, Zhou T, Edberg JC, Kimberly RP: Expression profile of Fc $\gamma$ RIIb on leukocytes and its dysregulation in systemic lupus erythematosus. J Immunol 2007, 178:3272-3280.

38. Mozo L, Suarez A, Gutierrez C: Glucocorticoids up-regulate constitutive interleukin-10 production by human monocytes. Clin Exp Allergy 2004, 34:406-412.

39. Garrelds IM, van Hal PT, Haakmat RC, Hoogsteden HC, Saxena PR, Zijlstra FJ: Time dependent production of cytokines and eicosanoids by human monocytic leukaemia U937 cells: effects of glucocorticosteroids. Mediators Inflamm 1999, 8:229-235

40. Llorente L, Richaud-Patin Y, Wijdenes J, Alcocer-Varela J, Maillot MC, Durand-Gasselin I, Fourrier BM, Galanaud P, Emilie D: Spontaneous production of interleukin-10 by $B$ lymphocytes and monocytes in systemic lupus erythematosus. Eur Cytokine Netw 1993, 4:421-427.

41. Xia CQ, Peng R, Beato F, Clare-Salzler MJ: Dexamethasone induces IL-10-producing monocyte-derived dendritic cells with durable immaturity. Scand J Immuno/ 2005, 62:45-54.

42. Haas $C$, Ryffel $B$, Le Hir M: IFN- $\gamma$ is essential for the development of autoimmune glomerulonephritis in MRL/lpr mice. J Immunol 1997, 158:5484-5491.

43. Calvani N, Satoh $M$, Croker BP, Reeves $W H$, Richards $H B$ : Nephritogenic autoantibodies but absence of nephritis in II12p35-deficient mice with pristane-induced lupus. Kidney Int 2003, 64:897-905

44. Nacionales DC, Kelly-Scumpia KM, Lee PY, Weinstein JS, Lyons R, Sobel E, Satoh M, Reeves WH: Deficiency of the type I interferon receptor protects mice from experimental lupus. Arthritis Rheum 2007, 56:3770-3783.

45. Uhm WS, Na K, Song GW, Jung SS, Lee T, Park MH, Yoo DH: Cytokine balance in kidney tissue from lupus nephritis patients. Rheumatology (Oxford) 2003, 42:935-938.

46. Peterson KS, Huang JF, Zhu J, D'Agati V, Liu X, Miller N, Erlander $M G$, Jackson MR, Winchester RJ: Characterization of heterogeneity in the molecular pathogenesis of lupus nephritis from transcriptional profiles of laser-captured glomeruli. J Clin Invest 2004, 113:1722-1733.

47. Zhuang H, Narain S, Sobel E, Lee PY, Nacionales DC, Kelly KM, Richards HB, Segal M, Stewart C, Satoh M, Reeves WH: Association of anti-nucleoprotein autoantibodies with upregulation 
of type I interferon-inducible gene transcripts and dendritic cell maturation in systemic lupus erythematosus. Clin Immunol 2005, 117:238-250

48. Heller T, Gessner JE, Schmidt RE, Klos A, Bautsch W, Kohl J: Cutting edge: Fc receptor type I for IgG on macrophages and complement mediate the inflammatory response in immune complex peritonitis. J Immunol 1999, 162:5657-5661.

49. Saito T, Yusa A, Soma J, Ootaka T, Sato H, Ito S: Significance of leukocyte infiltration in membranous nephropathy with segmental glomerulosclerosis. Nephron 1998, 80:414-420.

50. Yang N, Isbel NM, Nikolic-Paterson DJ, Li Y, Ye R, Atkins RC, Lan HY: Local macrophage proliferation in human glomerulonephritis. Kidney Int 1998, 54:143-151.

51. Weidner S, Carl M, Riess R, Rupprecht HD: Histologic analysis of renal leukocyte infiltration in antineutrophil cytoplasmic antibody-associated vasculitis: importance of monocyte and neutrophil infiltration in tissue damage. Arthritis Rheum 2004, 50:3651-3657.

52. Clynes R, Maizes JS, Guinamard R, Ono M, Takai T, Ravetch JV: Modulation of immune complex-induced inflammation in vivo by the coordinate expression of activation and inhibitory Fc receptors. J Exp Med 1999, 189:179-185. 